\title{
Association between Refractive Error Types and Asthenopia in Primary School Students
}

\author{
Vanessa Kuswanto, ${ }^{1}$ Felicia Kurniawan, ${ }^{2}$ Angela Shinta Dewi Amita ${ }^{3}$ \\ ${ }^{1}$ Faculty of Medicine and Health Sciences Atma Jaya Catholic University, Indonesia, \\ ${ }^{2}$ Department of Public Health and Nutrition Faculty of Medicine Atma Jaya Catholic University, Indonesia, \\ ${ }^{3}$ Department of Ophthalmology Faculty of Medicine Atma Jaya Catholic University, Indonesia
}

\begin{abstract}
Refractive error is a condition in which the cornea and lens fail to focus the light, resulting in reduced visual efficiency. Twelve million children are experiencing refractive errors worldwide and uncorrected refractive errors in children have been reported to cause asthenopia. This study aimed to determine the association between the types of refractive errors and asthenopia in children. This cross-sectional study was conducted on 111 students aged 10-13 years old in a public elementary school in Indonesia, SDN Penjaringan 10, in 2019. A questionnaire was used to assess asthenopia and the Snellen Chart, trial frames, and trial lenses were used for refractive errors examination. It was demonstrated that $87.4 \%$ of respondents experienced asthenopia, and $53.2 \%$ of respondents suffered from uncorrected refractive errors, mostly due to myopia. Fisher's exact test results showed an association between refractive errors and asthenopia $(p=0.019)$ with all myopic students experienced asthenopia. However, there was no significant association between astigmatism and asthenopia $(p=0.754)$. In conclusion, not all types of refractive errors are associated with asthenopia.
\end{abstract}

Keywords: Asthenopia, refractive error, Primary School Students

\section{Hubungan antara Jenis Kelainan Refraksi dengan Astenopia pada Anak Sekolah Dasar}

\begin{abstract}
Abstrak
Kelainan refraksi menggambarkan kondisi di mana kornea dan lensa gagal memfokuskan cahaya yang masuk sehingga menyebabkan efisiensi visual berkurang. Terdapat 12 juta anak mengalami kelainan refraksi di seluruh dunia. Kelainan refraksi yang tidak terkoreksi pada anak dilaporkan dapat menyebabkan astenopia. Penelitian ini bertujuan mengetahui hubungan antara jenis kelainan refraksi dengan astenopia pada anak sekolah dasar. Penelitian ini menggunakan metode potong lintang pada 111 anak usia 10-13 tahun di Sekolah Nasional Negeri 10 Penjaringan Indonesia pada tahun 2019. Kuesioner digunakan untuk menilai astenopia. Snellen Chart, bingkai percobaan, dan lensa percobaan digunakan untuk pemeriksaan kelainan refraksi. Penelitian ini menunjukkan sebanyak $87,4 \%$ responden mengalami astenopia, dan 53,2\% responden mengalami kelainan refraksi yang tidak terkoreksi, sebagian besar mengalami miopia. Hasil uji eksak Fisher menunjukkan terdapat hubungan antara kelainan refraksi dengan astenopia $(\mathrm{p}=0.019)$, semua anak yang menderita miopia mengalami astenopia, namun tidak ada hubungan signifikan antara astigmatisme dan astenopia $(p=0.754)$. Simpulan, tidak semua jenis kelainan refraksi berhubungan dengan astenopia.
\end{abstract}

Kata kunci: Astenopia, kelainan refraksi, Anak Sekolah Dasar

Corresponding Author: Vanessa Kuswanto, Faculty of Medicine and Health Sciences Atma Jaya Catholic University, Jalan Pluit Selatan Raya No. 19, DKI Jakarta 14440, Indonesia, Email: kuswantovanessa@gmail.com 


\section{Introduction}

The number of people with visual impairments and blindness continue to increase in Indonesia, which has a high prevalence when compared to other Southeast Asian countries. The Ministry of Health of the Republic of Indonesia reported that refractive errors are the second cause of visual disturbances and blindness after glaucoma. ${ }^{1}$ Refractive disorders begin to appear at the age of 6-11 years, and may continue to develop and persist by the age of 12 and above. Children with a refractive error tend not to complain and do not share their visual problems with others. Since they are only showing symptoms on their daily basis without any knowledge of their condition, they need special attention from their surroundings, especially from the parents and teachers. Uncorrected refractive errors can cause complications such as amblyopia or even blindness; thus, it must be detected as early as possible. ${ }^{2}$ Asthenopia is a condition of pain and fatigue in the eyes, usually due to excessive use of the eyes for a certain period of time. The symptoms include blurred vision, double vision, photophobia, feeling of dryness, foreign body sensation, eye ache, headache, burning, and itch, which may interfere with the child's attention, learning process, and academic performance. There are two categories of asthenopia: external and internal asthenopia.The external asthenopia is triggered by insufficient ambient conditions, such as the quality and the quantity of lighting or the objects seen. On the other hand, internal asthenopia is caused by the ocular status, such as accommodative dysfunction and extraocular muscle imbalance. Despite the fact that several previous studies reported uncorrected refractive errors as causing asthenopia symptoms, other studies found no association between refractive anomalies and asthenopia. This study aims to see the relationship between different types of refractive error, especially astigmatism and myopia, experienced by schoolchildren., ${ }^{3,4}$

\section{Methods}

A cross-sectional study was performed in the month of November, 2019 and involved 111 children aged 10-13 years who were in grade 5 and 6 of Public Elementary School 10, North Jakarta, Indonesia, as respondents. The Ethics Research Committee of the Faculty of Medicine, University of Atma Jaya has approved this study through the issuance of the ethical clearance number 07/02/KEP-FKUAJ/2020. Children who are sick or unwell, have history of diseases or eye surgeries which give complications similar to asthenopia, and those with ocular anatomical abnormalities, amblyopia, and strabismus were excluded. Children who manifested heterotropia were also excluded.

This study used the Asthenopia Questionnaire developed by Husnun et al. ${ }^{6}$ that have been tested and validated in Indonesian. There are 15 items of symptoms in the questionnaire that receive score from 0 for never to 1 for infrequent; 2 for occasionally; 3 for relatively frequent; 4 for frequent; and 5 for always. A total score of $\geq 9$ indicates positive symptoms for asthenopia, while a subject with a total score of $<9$ indicates negative symptoms or does not have asthenopia. The questionnaire was modified by adding a range of time of 20 minutes, referring to the 20 20-20 rule theory, that asthenopia symptoms will likely to appear after 20 minutes of excessive eye usage. ${ }^{7}$ Respondents underwent an examination of their general condition, followed by completing the questionnaire and a physical examination of the anterior eyes to examine the cornea, lens, and position of the eyeball. The subjective refractive error examination was carried out using the Snellen charts, trial frames, and trial lenses. The completion of the questionnaire and the examination were performed in the middle of school hours as asthenopia is expected to appear after some close works in the classes. Myopia was identified if the spherical equivalent reached $\geq 0.5$ diopters (D), hyperopia if $\geq+0.5 \mathrm{D}$, and astigmatism if the cylinder error reached $\geq 0.5$ diopter cylinder (DC) in any axis. ${ }^{8}$ The diagnosis of the refractive errors is based on the eye with more severe refractive errors or greatest SE values. The statistical analysis for this study was conducted using the SPSS version 21.0 to perform Fisher-exact test with the limit of significance test of 0.05 .

\section{Results}

The total number of respondents in this study was 111, consisting of schoolchildren aged 1013 years old with male gender and $6^{\text {th }}$ graders in dominance, as shown in Table 1. Most of them experienced sthenopia symptoms and refractive errors with none had hyperopia. There were 59 respondents (53.2\%) who had uncorrected refractive errors, while 52 respondents $(46.8 \%)$ did not have refractive errors. In addition, 43 children had normal eyes (emmetropia) and the 
V Kuswanto et al: Association between Refractive Error Types and Asthenopia in Primary School Students

Table 1 Characteristics of Students in Public Elementary School ${ }^{10}$

\begin{tabular}{lcc}
\hline \multicolumn{1}{c}{ Variable } & Frequency $(\mathbf{n = 1 1 1})$ & \% \\
\hline Sex & 58 & 52.3 \\
Male & 53 & 47.7 \\
Female & & \\
Grade & 52 & 46.8 \\
5 & 59 & 53.2 \\
6 & & \\
Asthenopia & 97 & 87.4 \\
Yes & 14 & 12.6 \\
No & & \\
Refractive Error & 52 & 46.8 \\
Corrected & 27 & 24.3 \\
Myopia & 25 & 22.5 \\
Compound myopic astigmatism & 5 & 4.5 \\
Astigmatism & 1 & 0.9 \\
Compound hyperopic astigmatism & 1 & 0.9 \\
Mixed astigmatism & & \\
\hline
\end{tabular}

remainings were respondents with refractive errors but had been optimally corrected with a daily use of glasses.

A total of 97 respondents who experienced asthenopia were distributed based on the type of symptoms experienced. The most frequent symptom was drowsiness $(96.9 \%)$, while the least experienced symptom was seeing floating or moving texts $(15.5 \%)$.

Almost all respondents with uncorrected refractive errors experienced the symptoms of asthenopia (94.9\%). The p-value of 0.019 was obtained as seen in Table 3; therefore, there was an association between refractive errors and asthenopia among the students. Table 4 demonstrates an association between myopia and asthenopia with a p-value of 0.020. All types of astigmatism were combined and analyzed for the association with asthenopia. As seen in Table 5 , the p-value was 0.754 , meaning that there was no significant association between astigmatism and asthenopia.

Table 2 Asthenopia Symptoms Survey in Public Elementary School ${ }^{10}$

\begin{tabular}{lcc}
\hline \multicolumn{1}{c}{ Asthenopia Symptoms } & Frequency & \% \\
\hline Eye fatigue & 84 & 86.6 \\
Eye redness & 32 & 33.0 \\
Heaviness in eye & 65 & 67.0 \\
Dry eye & 49 & 50.5 \\
Drowsiness & 94 & 96.9 \\
Difficulty of recalling recent reading & 70 & 72.2 \\
Periocular pain & 46 & 47.4 \\
Parietal/occipital headache & 83 & 85.6 \\
Blurred vision & 68 & 70.1 \\
Double vision when doing close work & 46 & 47.4 \\
Line skipping during reading & 92 & 94.8 \\
Confusion during reading & 87 & 89.7 \\
\hline
\end{tabular}


Table 3 Association between Refractive Errors and Asthenopia

\begin{tabular}{llrlrl}
\hline \multirow{2}{*}{ Refractive Errors } & \multicolumn{2}{c}{ Asthenopia } & \multirow{2}{*}{ Total (\%) } & \multirow{2}{*}{ P Value } \\
\cline { 2 - 3 } & \multicolumn{2}{c}{ Yes (\%) } & No (\%) & & \\
\hline Yes & $56(94.9)$ & $3(5.1)$ & $59(53.2)$ & 0.019 \\
No & $41(78.8)$ & $11(21.2)$ & $52(46.8)$ & \\
\hline
\end{tabular}

Table 4 Association between Myopia and Asthenopia

\begin{tabular}{lcccc}
\hline \multirow{2}{*}{ Myopia } & \multicolumn{2}{c}{ Asthenopia } & Total (\%) & \multirow{2}{*}{ P Value } \\
\hline Yes & Yes (\%) & No (\%) & $27(24.3)$ & 0.020 \\
No & $27(100)$ & $0(0.0)$ & $84(75.7)$ & \\
\hline
\end{tabular}

\section{Discussion}

Of all respondents participating in this study, 97 (87.4\%) experienced the symptoms of asthenopia. A previous study, which was conducted on 60 students, showed that the prevalence of asthenopia was $96.6 \%$. The difference between these results is due to unsuitable lighting design of the school building and the poor conditions of the building in the previous study, which is a contributing factor of asthenopia. ${ }^{9}$ Another study suggested a prevalence of asthenopia of $24.7 \%$ among first to eighth graders in Brazil. The contrast of these results could be due to the differences of age ranges. By and large, it is to be said that asthenopia is significantly linked to age, in which children aged $10-14$ years are $51 \%$ more likely to suffer from asthenopia rather than children aged 6-9 years. ${ }^{3}$

This study also revealed that there is an association between refractive errors, especially myopia, and asthenopia. This result is similar with a study in India on children under 16 years old where asthenopia was identified in $82.2 \%$ of children with ametropic eyes with significant association. The study also stated that overall asthenopia symptoms were mostly found in myopic patients (81\%), followed by hyperopic patients with $72.9 \%{ }^{10}$ Myopia causes a physiological accommodative response in the eyes, where patients may need a closer distance to be able to see objects comfortably. This close distance requires greater convergence, leading to asthenopia symptoms. These symptoms can be reduced by wearing appropriate prescription eyeglasses. ${ }^{7,11}$

No significant relationship is found between astigmatism and asthenopia among participants in this study ( $p=0.754)$. A study in Lahore showed a similar result, whereasthenopia symptoms such as eye pain, blurry eyes, itching, double vision, watery eyes were experienced by $47 \%$ of hyperopic patients, $23 \%$ of myopic patients, and $7 \%$ of astigmatic patients. Astigmatism causes fewer symptoms than other types of refractive error. ${ }^{11}$ However, these results are dissimilar to a study in Brazil that showed mixed astigmatism, myopic astigmatism, and hyperopia astigmatism to be significantly associated with the onset of asthenopia. ${ }^{12}$

It is stated that the asthenopia symptoms depend on the type and severity of astigmatism. A previous study in India found that againstthe-rule astigmatism causes blurry vision and worsen asthenopia symptoms when compared to oblique astigmatism, as well as with-the-rule

Table 5 Association between Astigmatism and Asthenopia

\begin{tabular}{lcccc}
\hline \multirow{2}{*}{ Astigmatism } & \multicolumn{2}{c}{ Asthenopia } & \multirow{2}{*}{ Total (\%) } & P Value \\
\hline Yes & Yes (\%) & No (\%) & & \\
No & $29(90.6)$ & $3(9.4)$ & $32(28.8)$ & \multirow{2}{*}{0.754} \\
\hline
\end{tabular}


astigmatism, that are generally found in young people. In this study, with-the-rule astigmatism was dominant. ${ }^{13}$ Some prior studies did not use the same questionnaire and cut-offs to diagnose asthenopia. This dissimilarities are contributed by the absence of a standardized questionnaire or a gold standard instrument for assessing asthenopia. Nevertheless, all population-based studies on asthenopia was performed with a subjective questionnaire ${ }^{3}$

There are some external factors that affect asthenopia symptoms, for example, the quality and the quantity of illuminations, excessive usage of computer monitors, poor ergonomics, working conditions, as well as the environmental factors. In this study, the Public National School Penjaringan 10 has sufficient lighting installation that evenly distributes and illuminates the entire classroom. In addition, it also has standardized classroom tables and chairs for primary school students. This school also does not have any computer lab, and they forbid electronic devices usage for students during school hours. Another factor affecting asthenopia is the general condition of the subject, such as lacking sleep or feeling unwell. In this study, this factor was successfully excluded during general condition examinations. However, this study also carries some limitations in this study including the lack of data regarding other biased variables due to the limited time of the study such as respondent's activities outside school hours, AC/A ratio, or near-point convergence value. . $^{14,15}$

Hence, the most common type of refractive error identified among primary school students was myopia, and mostly are still uncorrected. An association is identified between refractive errors and asthenopiam as evident from the observation that all myopic students suffer from asthenopia symptoms. However, no significant association is found between astigmatism and asthenopia. This study recommends further ocular examination and more intensive interview regarding the presence of asthenopia symptoms in future research.

\section{References}

1. Fauzi L. Skrining kelainan refraksi mata pada siswa sekolah dasar menurut tanda dan gejala. Journal Health Education. 2016;1(1):78-84

2. Amalia T. Prevalensi dan penyebab kelainan refraksi pada anak usia sekolah di Sekolah Dasar Muhammadiyah 16 Palembang
[Thesis]. Palembang: Repository Universitas Muhammadiyah Palembang; 2016.

3. FassaVilela M, Castagno V, Meucci R, Fassa A. Asthenopia in Schoolchildren. Clinical Ophthalmology Dovepress. 2015;9:1595603.

4. Wajuihian SO. Frequency of asthenopia and its association with refractive errors. African Vision and Eye Health. 2015;74(1).Art. \#293.

5. Hashemi H, Khabazkhoob M, Forouzesh S, Nabovati P, Yekta A, Ostadimoghaddam $\mathrm{H}$. The prevalence of asthenopia and its determinants among Schoolchildren. J Compr Ped. 2017;8(1):e43208.

6. Fernanda, N. Amalia, H. Hubungan akomodasi insufisiensi dan astenopia pada remaja di Jakarta Barat. J Biomed Kes 2018;1(1):10-7.

7. [AAO]. American Academy of Ophthalmology. Computers, digital devices and eye strain 2016. [11 Nov 2019]. Available from: https://www.aao.org/eye-health/tipsprevention/computer-usage.

8. Althomali TA. Relative proportion of different types of refractive errors in subjects seeking laser vision correction. Open Ophthalmol J. 2018;12:53-62.

9. Djupri AG. Pengaruh intensitas penerangan terhadap kelelahan mata pada siswa Kelas IV Dan V Sekolah Dasar Negeri 02 Kuripan-Purwodadi [thesis]. Surakarta: Fakultas Ilmu Kesehatan Universitas Muhammadiyah Surakarta; 2013.

10. Gupta R, Sharma B, Anand R, Bawaria S, Dewada R. Association of asthenopia and convergence insufficiency in children with refractive error- a hospital based study. Int J Med Res Rev. 2013; 1(5):222-27.

11. Mohamud MD. Frequency of presenting clinical features of asthenopia (ocular fatigue) in refractive patients. College Ophthalmology \& Allied Vision Sciences (COAVS) Pakistan. 2017;7(3):15-9.

12. Schellini S, Ferraz F, Opromolla P, Oliveira L, Padovani C. Main Visual Symptoms associated with refractive errors and spectacle need in a Brazilian. Int J ophthalmol. 2016; 9(11):1657-62.

13. Prabhu P, Faseena N. Role of refractive errors in inducing asthenopic symptoms among spectacle corrected ammetropes. BMH Med. J. 2016;3(2):32-36.

14. Hanum IF. Efektivitas penggunaan screen pada monitor komputer untuk mengurangi kelelahan mata pekerja call centre Di PT. Indosat NSR Tahun 2008 [thesis]. Medan: 
V Kuswanto et al: Association between Refractive Error Types and Asthenopia in Primary School Students

Universitas Sumatra Utara; 2008.

15. Affandi ES. Sindrom penglihatan komputer (computer vision syndrome). Universitas
Indonesia Penyegar Ilmu Kedokteran Maj Kedokt Indon. 2005;55(3):297-300. 